\title{
Spatial and Seasonal Assessment of Heavy Metals in Surface Waters of the Middleton River in the Niger Delta, Nigeria
}

\author{
Ayobami Aigberua*, Timi Tarawou, Cyprian Abasi \\ Department of Chemical Sciences, Faculty of Science, Niger Delta University, Wilberforce Island, Nigeria \\ Email address: \\ ozedee101@gmail.com (A. Aigberua) \\ ${ }^{*}$ Corresponding author
}

To cite this article:

Ayobami Aigberua, Timi Tarawou, Cyprian Abasi. Spatial and Seasonal Assessment of Heavy Metals in Surface Waters of the Middleton River in the Niger Delta, Nigeria. International Journal of Natural Resource Ecology and Management. Vol. 2, No. 5, 2017 , pp. $94-98$. doi: $10.11648 /$ j.ijnrem.20170205.12

Received: October 5, 2017; Accepted: October 19, 2017; Published: November 15, 2017

\begin{abstract}
This study was aimed at assessing the bioavailability of heavy metals in the surface water of the Middleton river which is a tributary of the river Nun located in the Niger Delta area of Nigeria. Samples were collected at points within and around oil and gas installations in the area while control points were chosen farther from identified pollution point sources. Three replicate samples were collected for each sampling and control location on a biannual basis for two months (March and August 2017) to reflect the dry and wet seasons respectively. A total of forty-two surface water samples were analyzed for heavy metals using standard methods as given in APHA. Heavy metal variables which were examined indicated significant difference between the locations and the two seasons under study $(\mathrm{p}<0.05)$. Dry season heavy metals mean were: $\mathrm{Fe}(6.55 \pm$ $2.36 \mathrm{mg} / \mathrm{l}$ and $7.39 \pm 1.35 \mathrm{mg} / \mathrm{l}) ; \mathrm{Cr}(0.43 \pm 0.09 \mathrm{mg} / \mathrm{l}$ and $0.34 \pm 0.02 \mathrm{mg} / \mathrm{l}) ; \mathrm{Mn}(0.22 \pm 0.31 \mathrm{mg} / \mathrm{l}$ and $0.02 \pm<0.01 \mathrm{mg} / \mathrm{l})$ and $\mathrm{Zn}(0.04 \pm 0.03 \mathrm{mg} / \mathrm{l}$ and $0.01 \pm<0.01 \mathrm{mg} / \mathrm{l})$ representing five sampling and two control locations respectively. Wet season heavy metal mean levels were relatively lower when compared to the dry season and depicted values of $\mathrm{Fe}(4.91 \pm 2.55 \mathrm{mg} / \mathrm{l}$ and $5.46 \pm 2.09 \mathrm{mg} / \mathrm{l}) ; \mathrm{Cr}(0.27 \pm 0.05 \mathrm{mg} / \mathrm{l}$ and $0.23 \pm 0.01 \mathrm{mg} / \mathrm{l}) ; \mathrm{Mn}(0.13 \pm 0.25 \mathrm{mg} / \mathrm{l}$ and $<0.01 \pm<0.01 \mathrm{mg} / \mathrm{l})$ and $\mathrm{Zn}(0.01$ $\pm 0.01 \mathrm{mg} / \mathrm{l}$ and $<0.01 \pm<0.01 \mathrm{mg} / \mathrm{l})$ across five sampling and two control locations respectively. All other heavy metals analyzed such as $\mathrm{Cd}, \mathrm{Ni}, \mathrm{Co}, \mathrm{Pb}$, and $\mathrm{Cu}$ was found to be below the detection limit of the GBC Avanta PM A6600 - Flame Atomic Absorption Spectrophotometer. The iron and chromium levels found in the Middleton river exceeded permissible limits of DPR, FME, WHO and NESREA while chromium and zinc were within permissible limits of regulatory stipulations. Lower concentration of heavy metals in the wet season could be due to dilution effects while the absence of undetected heavy metals may depict that activities leaching out this heavy metals are not common in the study area.
\end{abstract}

Keywords: Bioavailability, Physicochemical Parameters, Middleton River, Niger Delta, Water Quality

\section{Introduction}

Middleton river is a creek located in the Southern Ijaw local government area of Bayelsa state, the river is also referred to as Middleton creek, Middleton or Sagpetoru river. Its geographical coordinates lie within the latitude $4^{\circ} 30^{\prime} 30.49^{\prime}$ ' $\mathrm{N}$ and longitude $5^{\circ} 43^{\prime} 39.94$ " $\mathrm{E}$ and is bound by neighboring communities such as Babatoriagbene, Oporogbene, Kulama, Jituagbene, Beyentoro amongst others. The Middleton river is home to numerous oil and gas installations within the Niger Delta area as it is dotted with a number of oil wells and manifolds that serve as supply lines to neighboring oil flow stations. The area is therefore characterized by a network of underwater oil pipelines that move crude oil and gas; oil bunkering activities are predominant in this area while pipeline vandalism is not uncommon. The river is tidal and sometimes overflows, driving spilt crude into surrounding freshwater, mangrove swamps and mudflats, hence, the aquatic environment intermittently reflects oil sheen. In addition, other forms of indiscriminate and uncontrolled municipal discharges negatively impact on the overall quality of the aquatic environment. 
Corrosion of pipelines and tankers, sabotage and oil production operations accounts for $50 \%, 36 \%$ and $6.5 \%$ of oil spill incidence in Nigeria [1]. Generally, oil spills is a big threat to the environment in producing region because it can lead to accumulation of toxic substances such as heavy metals into the environment $[2,3]$. Oil spill occurs in nearly all phase crude oil processing from exploration to final use [4-6]. Heavy metal contamination has significant impact on the quality of water bodies [7]. Regular quantitative and qualitative assessment of the physicochemical parameters of surface water bodies is key to detection of water quality changes particularly, in inland creeks and rivers receiving municipal run-offs and industrial wastes discharges. The management and conservation of the aquatic ecosystem would therefore, depend on the knowledge of the physicochemical and biological properties of the surface water body [8]. It is imperative that concerned stakeholders carry out routine monitoring checks and maintenance on their numerous pipelines right of way to serve as stop gap measure for repetitive future occurrence of incessant pipeline vandalism [6].

It is extensively demonstrated that increasing heavy metal pollution from various industry constitutes environmental hazard for humans and other living things [9]. A number of events affecting water quality have resulted in increased public concern about surface water quality [10 - 16]. Such events as increased domestic wastes generation and indiscriminate disposal and discharge of untreated and poorly treated industrial wastes into surface water bodies impact negatively on water quality and lead to water quality deterioration [17 - 24]. Heavy metals associated with crude oil include $\mathrm{Pb}, \mathrm{Cd}, \mathrm{Cu}, \mathrm{Zn}, \mathrm{Ni}, \mathrm{V}$ and $\mathrm{Cr}$ amongst others [24]. Diseases and pathological conditions related to heavy metal contaminants have been recently reviewed by Izah et al. [10], Izah and Srivastav [11]. The aim of this study was to assess the surface water quality of the Middleton river using heavy metals as pollution indicators.

\section{Materials and Method}

\subsection{Study Area and Sample Collection}

The study area is the Middleton river located in Southern Ijaw local government area of Bayelsa state. Three replicate samples were collected for each sampling and control location on a biannual basis for two months (March and August 2017) to reflect the dry and wet seasons respectively. A total of forty-two surface water samples were collected and analyzed for heavy metal variables. The five sampling points were labeled $(\mathrm{A}-\mathrm{E})$ while two control points were taken across two flanks of the sampling points and labeled Control 1 and $2-$ Figure 1 .

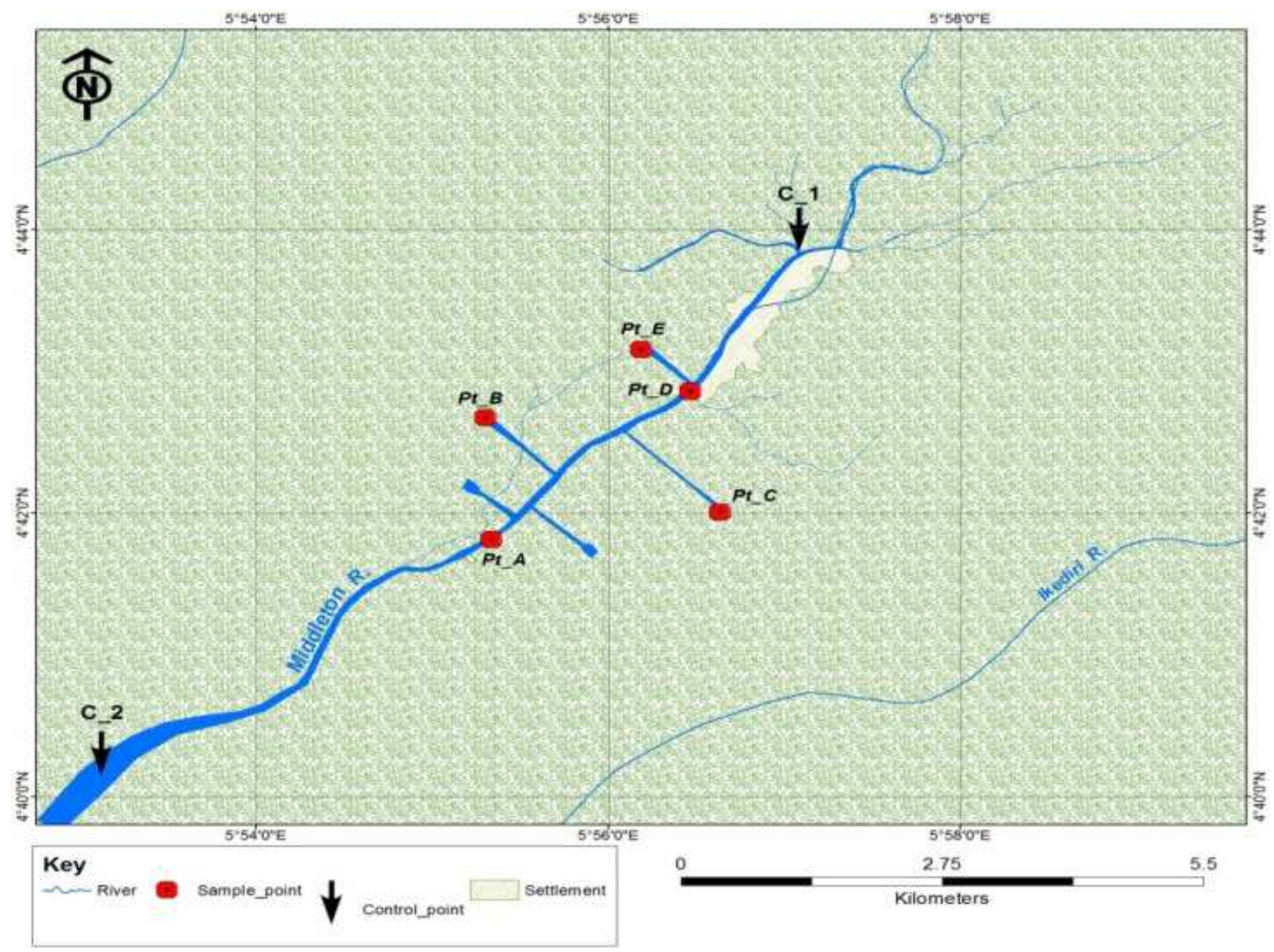

Figure 1. Location of sample and Control points. 


\subsection{Sample Handling}

One liter plastic containers were used to collect samples and preserved with nitric acid; samples were stored in ice chest while in transit to the laboratory. Heavy metal test procedure as described in Standard Methods for the Examination of Water and Waste water analysis by APHA [25] was adopted in the analysis of surface water samples.

\subsection{Sample Digestion and Heavy Metal Determination}

Samples were acid-digested by transferring $50 \mathrm{ml}$ of wellmixed, acid-preserved water sample into $100 \mathrm{ml}$ borosilicate glass beakers. Thereafter, $5 \mathrm{ml}$ of nitric acid was added to sample with slow boiling and evaporating to $20 \mathrm{ml}$ volume of the acid mixture on a hot plate. The digested water sample was left to cool and filtered through whatman filter paper before being diluted to mark in a $50 \mathrm{ml}$ volumetric flask using distilled water. Afterwards, portions of the acid solution were aspirated into the flame atomic absorption spectrophotometer (Model: GBC Avanta PM A6600 FAAS), while concentrations of heavy metals of interest were acquired subject upon prior calibration of the instrument with metal specific standard solutions. Individual heavy metals was analyzed at varying wavelengths of $248.3,357.9,279.5$, 213.9, 228.8, 232.0, 240.7, 217.0 and $324.7(\mathrm{~nm})$ for $\mathrm{Fe}, \mathrm{Cr}$, $\mathrm{Mn}, \mathrm{Zn}, \mathrm{Cd}, \mathrm{Ni}, \mathrm{Co}, \mathrm{Pb}$ and $\mathrm{Cu}$ respectively.

\subsection{Statistical Analysis}

SPSS software was used to carry out the statistical analysis. Data was expressed as Mean \pm Standard deviation. A oneway analysis of variance was used to test for significant differences at $\mathrm{P}=0.05$ based on spatial distribution and Duncan multiple range test statistics was used to determine the source of the observed variation. t-test was used to show significant variation at $\mathrm{P}=0.05$ based on season.

\section{Result and Discussion}

Spatial and seasonal variations of heavy metal variables were illustrated in tables $1-3$. More specifically, Table 1 and 2 shows the spatial distribution of heavy metals in the Middleton river during the dry and wet seasons respectively, while Table 3 shows the seasonal distribution of heavy metals in the Middleton river. Iron, chromium, manganese and zinc depicted significant differences across spatial locations and seasons while cadmium, nickel, cobalt, lead and copper were observed to be below the detection limit of the flame atomic absorption spectrophotometer (FAAS), this indicates that activities leaching out this heavy metals are not common in the study area. Detected heavy metal concentrations were significantly different $(\mathrm{p}<0.05)$ between the seasons and also showed significant interaction $(\mathrm{p}<0.05)$ between locations. The significant difference between seasons can be summarized as follows: wet season $<$ dry season. In addition, the significant difference among detected metals can be depicted as (zinc $<$ manganese $<$ chromium $<$ iron) and (manganese $<$ zinc $<$ chromium $<$ iron) for the dry and wet seasons respectively (Table 1 and 2). Furthermore, iron concentration ranged from $3.814-10.005 \mathrm{mg} / \mathrm{l}$ and $2.700-9.012 \mathrm{mg} / \mathrm{l}$, chromium ranged from $0.296-0.535$ $\mathrm{mg} / \mathrm{l}$ and $0.196-0.320 \mathrm{mg} / \mathrm{l}$, manganese ranged from $0.019-$ $0.818 \mathrm{mg} / 1$ and $<0.001-0.013 \mathrm{mg} / 1$, while zinc ranged from $0.010-0.080 \mathrm{mg} / \mathrm{l}$ and $<0.001-0.027 \mathrm{mg} / \mathrm{l}$ for dry and wet seasons respectively, being significantly different $(\mathrm{P}<0.05)$ in most of the locations (Table 1 and 2). Statistically, dry season values were significantly higher when compared to wet season (Table 3). Lower concentration in wet season could be due to dilution effects.

Table 1. Spatial Distribution of heavy metals of the Middleton river, Bayelsa state, Nigeria during the Dry Season

\begin{tabular}{llllllllll}
\hline Locations & $\mathbf{F e}(\mathbf{m g} / \mathbf{l})$ & $\mathbf{C r}(\mathbf{m g} / \mathbf{l})$ & $\mathbf{M n}(\mathbf{m g} / \mathbf{l})$ & $\mathbf{Z n}$ (mg/l) & $\mathbf{C d}(\mathbf{m g} / \mathbf{l})$ & $\mathbf{N i}(\mathbf{m g} / \mathbf{l})$ & $\mathbf{C o}(\mathbf{m g} / \mathbf{l})$ & $\mathbf{P b}(\mathbf{m g} / \mathbf{l})$ & $\mathbf{C u}(\mathbf{m g} / \mathbf{l})$ \\
\hline A & $5.050 \pm 0.192 \mathrm{~b}$ & $0.392 \pm 0.012 \mathrm{~b}$ & $0.135 \pm 0.008 \mathrm{~d}$ & $0.010 \pm 0.002 \mathrm{a}$ & $<0.001 \pm 0.00$ & $<0.001 \pm 0.00$ & $<0.001 \pm 0.00$ & $<0.001 \pm 0.00$ & $<0.001 \pm 0.00$ \\
$\mathrm{~B}$ & $3.814 \pm 0.181 \mathrm{a}$ & $0.296 \pm 0.008 \mathrm{a}$ & $0.042 \pm 0.005 \mathrm{~b}$ & $0.031 \pm 0.006 \mathrm{~b}$ & $<0.001 \pm 0.00$ & $<0.001 \pm 0.00$ & $<0.001 \pm 0.00$ & $<0.001 \pm 0.00$ & $<0.001 \pm 0.00$ \\
$\mathrm{C}$ & $10.005 \pm 0.125 \mathrm{~g}$ & $0.535 \pm 0.040 \mathrm{e}$ & $0.818 \pm 0.025 \mathrm{e}$ & $0.080 \pm 0.008 \mathrm{~d}$ & $<0.001 \pm 0.00$ & $<0.001 \pm 0.00$ & $<0.001 \pm 0.00$ & $<0.001 \pm 0.00$ & $<0.001 \pm 0.00$ \\
$\mathrm{D}$ & $5.532 \pm 0.196 \mathrm{c}$ & $0.492 \pm 0.019 \mathrm{~d}$ & $0.030 \pm 0.005 \mathrm{ab}$ & $0.055 \pm 0.005 \mathrm{c}$ & $<0.001 \pm 0.00$ & $<0.001 \pm 0.00$ & $<0.001 \pm 0.00$ & $<0.001 \pm 0.00$ & $<0.001 \pm 0.00$ \\
E & $8.331 \pm 0.163 \mathrm{e}$ & $0.441 \pm 0.014 \mathrm{c}$ & $0.096 \pm 0.009 \mathrm{c}$ & $0.015 \pm 0.003 \mathrm{a}$ & $<0.001 \pm 0.00$ & $<0.001 \pm 0.00$ & $<0.001 \pm 0.00$ & $<0.001 \pm 0.00$ & $<0.001 \pm 0.00$ \\
Cntrl A & $8.619 \pm 0.028 \mathrm{f}$ & $0.363 \pm 0.008 \mathrm{~b}$ & $0.023 \pm 0.003 \mathrm{ab}$ & $0.011 \pm 0.003 \mathrm{a}$ & $<0.001 \pm 0.00$ & $<0.001 \pm 0.00$ & $<0.001 \pm 0.00$ & $<0.001 \pm 0.00$ & $<0.001 \pm 0.00$ \\
Cntrl B & $6.162 \pm 0.166 \mathrm{~d}$ & $0.324 \pm 0.011 \mathrm{a}$ & $0.019 \pm 0.003 \mathrm{a}$ & $0.016 \pm 0.004 \mathrm{a}$ & $<0.001 \pm 0.00$ & $<0.001 \pm 0.00$ & $<0.001 \pm 0.00$ & $<0.001 \pm 0.00$ & $<0.001 \pm 0.00$ \\
\hline
\end{tabular}

Data is expressed as mean \pm standard deviation $(\mathrm{n}=3)$; Different letters along the column indicate significant difference ( $<0.05)$ according to Duncan statistics.

Table 2. Spatial Distribution of heavy metals of the Middleton river, Bayelsa state, Nigeria during the Wet Season.

\begin{tabular}{|c|c|c|c|c|c|c|c|c|c|}
\hline Locations & $\mathrm{Fe},(\mathrm{mg} / \mathrm{l})$ & $\mathrm{Cr},(\mathrm{mg} / \mathrm{l})$ & Mn, (mg/l) & $\mathrm{Zn},(\mathrm{mg} / \mathrm{l})$ & $\mathrm{Cd},(\mathrm{mg} / \mathrm{l})$ & $\mathrm{Ni},(\mathrm{mg} / \mathrm{l})$ & $\mathrm{Co},(\mathrm{mg} / \mathrm{l})$ & $\mathrm{Pb},(\mathrm{mg} / \mathrm{l})$ & $\mathrm{Cu},(\mathrm{mg} / \mathrm{l})$ \\
\hline A & $3.325 \pm 0.128 \mathrm{c}$ & $0.303 \pm 0.033 \mathrm{de}$ & $0.013 \pm 0.003 a$ & $0.000 \pm 0.000 \mathrm{a}$ & $<0.001 \pm 0.00$ & $<0.001 \pm 0.00$ & $<0.001 \pm 0.00$ & $<0.001 \pm 0.00$ & $<0.001 \pm 0.00$ \\
\hline B & $2.700 \pm 0.111 \mathrm{a}$ & $0.196 \pm 0.012 \mathrm{a}$ & $0.000 \pm 0.000 \mathrm{a}$ & $0.004 \pm 0.001 b$ & $<0.001 \pm 0.00$ & $<0.001 \pm 0.00$ & $<0.001 \pm 0.00$ & $<0.001 \pm 0.00$ & $<0.001 \pm 0.00$ \\
\hline $\mathrm{C}$ & $9.012 \pm 0.297 f$ & $0.320 \pm 0.022 \mathrm{e}$ & $0.610 \pm 0.026 \mathrm{~b}$ & $0.027 \pm 0.003 \mathrm{~d}$ & $<0.001 \pm 0.00$ & $<0.001 \pm 0.00$ & $<0.001 \pm 0.00$ & $<0.001 \pm 0.00$ & $<0.001 \pm 0.00$ \\
\hline $\mathrm{D}$ & $3.033 \pm 0.151 b$ & $0.284 \pm 0.020 \mathrm{de}$ & $0.000 \pm 0.000 \mathrm{a}$ & $0.010 \pm 0.003 \mathrm{c}$ & $<0.001 \pm 0.00$ & $<0.001 \pm 0.00$ & $<0.001 \pm 0.00$ & $<0.001 \pm 0.00$ & $<0.001 \pm 0.00$ \\
\hline E & $6.493 \pm 0.109 d$ & $0.272 \pm 0.016 \mathrm{~cd}$ & $0.008 \pm 0.003 a$ & $0.000 \pm 0.000 \mathrm{a}$ & $<0.001 \pm 0.00$ & $<0.001 \pm 0.00$ & $<0.001 \pm 0.00$ & $<0.001 \pm 0.00$ & $<0.001 \pm 0.00$ \\
\hline Cntrl A & $7.174 \pm 0.089 \mathrm{e}$ & $0.239 \pm 0.017 b c$ & $0.000 \pm 0.000 \mathrm{a}$ & $0.000 \pm 0.000 \mathrm{a}$ & $<0.001 \pm 0.00$ & $<0.001 \pm 0.00$ & $<0.001 \pm 0.00$ & $<0.001 \pm 0.00$ & $<0.001 \pm 0.00$ \\
\hline Cntrl B & $3.564 \pm 0.135 \mathrm{c}$ & $0.221 \pm 0.003 \mathrm{ab}$ & $0.000 \pm 0.000 \mathrm{a}$ & $0.000 \pm 0.000 \mathrm{a}$ & $<0.001 \pm 0.00$ & $<0.001 \pm 0.00$ & $<0.001 \pm 0.00$ & $<0.001 \pm 0.00$ & $<0.001 \pm 0.00$ \\
\hline
\end{tabular}

Data is expressed as mean \pm standard deviation $(\mathrm{n}=3)$; Different letters along the column indicate significant difference ( $<0.05)$ according to Duncan statistics. 
Table 3. Seasonal variation of heavy metals of the Middleton river, Bayelsa state in comparison to different National and International standards.

\begin{tabular}{|c|c|c|c|c|c|c|c|c|}
\hline $\begin{array}{l}\text { Heavy } \\
\text { metals }\end{array}$ & $\begin{array}{l}\text { Dry season } \\
(n=21)\end{array}$ & $\begin{array}{l}\text { Wet season } \\
(n=21)\end{array}$ & t-value & p-value & $\begin{array}{l}\text { DPR Limits } \\
{[26]}\end{array}$ & $\begin{array}{l}\text { FMENV } \\
\text { Limits [27] }\end{array}$ & $\begin{array}{l}\text { NESREA } \\
\text { Limits [28] }\end{array}$ & $\begin{array}{l}\text { WHO Limits } \\
{[29]}\end{array}$ \\
\hline $\mathrm{Fe}, \mathrm{mg} / \mathrm{l}$ & $6.788 \pm 2.123$ & $5.043 \pm 2.362$ & 2.518 & 0.016 & 1.0 & 1.0 & 0.03 & - \\
\hline $\mathrm{Cr}, \mathrm{mg} / \mathrm{l}$ & $0.406 \pm 0.085$ & $0.262 \pm 0.046$ & 6.857 & 0.000 & 0.03 & 0.02 & 0.10 & 0.05 \\
\hline $\mathrm{Zn}, \mathrm{mg} / \mathrm{l}$ & $0.031 \pm 0.026$ & $0.006 \pm 0.000$ & 4.209 & 0.000 & 1.0 & 0.03 & 1.5 & 3 \\
\hline $\mathrm{Co}, \mathrm{mg} / \mathrm{l}$ & $<0.001 \pm 0.000$ & $<0.001 \pm 0.000$ & NA & NA & - & - & - & - \\
\hline $\mathrm{Cd}, \mathrm{mg} / \mathrm{l}$ & $<0.001 \pm 0.000$ & $<0.001 \pm 0.000$ & NA & NA & - & 0.002 & 0.01 & 0.003 \\
\hline $\mathrm{Ni}, \mathrm{mg} / \mathrm{l}$ & $<0.001 \pm 0.000$ & $<0.001 \pm 0.000$ & NA & NA & 0.15 & - & 0.02 & 0.15 \\
\hline $\mathrm{Cu}, \mathrm{mg} / \mathrm{l}$ & $<0.001 \pm 0.000$ & $<0.001 \pm 0.000$ & NA & NA & 1.5 & 0.004 & 0.05 & 2 \\
\hline
\end{tabular}

Generally, the heavy metals (cobalt, cadmium, lead, nickel and copper) depicted the value of $<0.001$ across the dry and wet seasons respectively, therefore the activities which characterize the Middleton river may not have bioconcentrated the aquatic environment with these metals. The mean concentration of heavy metals present in the surface water samples during the dry season was depicted as: iron $(6.55 \pm 2.36 \mathrm{mg} / 1$ and $7.39 \pm 1.35 \mathrm{mg} / \mathrm{l})$, chromium $(0.43$ $\pm 0.03 \mathrm{mg} / 1$ and $0.01 \pm<0.01 \mathrm{mg} / \mathrm{l})$, manganese $(0.22 \pm 0.31$ $\mathrm{mg} / \mathrm{l}$ and $0.02 \pm<0.01 \mathrm{mg} / \mathrm{l})$ and zinc $(0.04 \pm 0.03 \mathrm{mg} / \mathrm{l}$ and $0.01 \pm<0.01 \mathrm{mg} / \mathrm{l})$ for sample and control points respectively. Similarly, the mean concentration of heavy metals present in the surface water samples during the wet season was depicted as: iron $(4.91 \pm 2.55 \mathrm{mg} / \mathrm{l}$ and $5.46 \pm 2.09 \mathrm{mg} / \mathrm{l})$, chromium $(0.27 \pm 0.05 \mathrm{mg} / \mathrm{l}$ and $0.23 \pm 0.01 \mathrm{mg} / \mathrm{l})$, manganese $(0.13 \pm$ $0.25 \mathrm{mg} / \mathrm{l}$ and $<0.01 \pm<0.01 \mathrm{mg} / \mathrm{l})$ and zinc $(0.01 \pm 0.01 \mathrm{mg} / 1$ and $0.01 \pm<0.01 \mathrm{mg} / \mathrm{l})$. The mean levels of iron $(\mathrm{Fe})$ observed in the Middleton river was higher during the dry season when compared to the mean values measured at the control points while the measured mean levels of iron were higher at the control points when compared to the sample locations. This may not be unconnected with the redistribution and cross-contamination of the control points which lie along the same axis of the river. Mean levels of chromium, manganese and zinc were higher at the sample locations when compared with control points across the dry and wet seasons; this may have resulted from dilution effects.

Mean levels of iron exceeded permissible regulatory limitations of the department of petroleum resources [26], federal ministry of environment [27], national environmental standards and regulation enforcement agency [28] and world health organization [29] for the sample locations and control points as well as both seasons (Table 3) while mean chromium concentrations exceeded regulatory limitations at the sample locations across both seasons and at control points during the wet season; however, mean chromium concentrations were within permissible limitations at the control points during the dry season. Also, mean levels of manganese and zinc were within permissible regulatory limitations across both seasons and locations while it is worthy of note that all other test metals were below the detection limit of the instrument.

\section{Conclusion}

Heavy metal concentrations showed significant variations across seasons and locations as the role of natural climatic conditions such as river tidal currents, rainfall and atmospheric temperature/humidity play a role in the redistribution of these persistent heavy metal pollutants. The marked availability of iron may have likely been derived naturally from crustal weathering of underlying sediments while the significant levels of chromium may have stemmed from industrial activities within the environment or from the corrosion of underlying oil pipelines. The significance of this is that the water derived from the Middleton river may not be fit for domestic use as it may portend adverse health implications over time. It is therefore pertinent that regular monitoring of the Middleton river be sustained to ensure regulatory compliance and to safeguard the environment in view of its overall economic importance.

\section{References}

[1] Adelana, S., Adeosun, T. A., Adesina, A. and Ojuroye, M. (2011). Environmental pollution and remediation: challenges and management of oil spillage in the Nigerian coastal areas. American Journal of Science and Industrial Research, 2 (6): 834-845.

[2] Kadafa, A. A. (2012). Environmental Impacts of Oil Exploration and Exploitation in the Niger Delta of Nigeria. Global Journal of Science Frontier Research Environment \& Earth Sciences. 12 (3): 19-27.

[3] Kadafa, A. A. (2012). Oil exploration and spillage in the Niger delta of Nigeria. Civil and Environmental Research 2 (3): $38-51$.

[4] Aigberua, A. O., Ekubo, A. T., Inengite, A. K. and Izah, S. C. (2016). Seasonal variation of nutrient composition in an oil spill contaminated soil: a case of Rumuolukwu, Eneka, Port Harcourt, Nigeria. Biotechnological Research, 2 (4): 179-186.

[5] Aigberua, A. O., Ekubo, A. T., Inengite, A. K. and Izah, S. C. (2016). Evaluation of Total Hydrocarbon Content and Polycyclic Aromatic Hydrocarbon in an Oil Spill Contaminated Soil in Rumuolukwu Community in Niger Delta. Journal of Environmental Treatment Techniques, 4 (4): 130-142.

[6] Aigberua, A. O., Ekubo, A. T., Inengite, A. K. and Izah, S. C. (2017). Assessment of some selected heavy metals and their pollution indices in an oil spill contaminated soil in the Niger Delta: a case of Rumuolukwu community. Biotechnol Res 3 (1): $1-5$. 
[7] Peng, J.-F., Song, Y.-H., Yuan, P., Cui, X.-Y. and Qiu, G.-I. (2009). The remediation of heavy metals contaminated sediment. Journal of Hazardous Materials, 161 (2): 633-640.

[8] Moslen, M., Daka, E. R., Ekeh, C. A. and Ekweozor, I. K. E. (2006). Physicochemical properties of two estuarine creeks in the Niger Delta in relation to urban/industrial activities. Niger Delta Biologia 5 (2): 115-122.

[9] Uluturhan, E. and Kucuksezgin, F. (2007). Heavy Metal Contaminants in Red Pandora (Pagellus erythrinus) tissues from the Eastern Aegean Sea, Turkey. Water Research, 41 (6): 1185-1192. Doi:

http://dx.doi.org/10.1016/j.watres.2006.11.044.

[10] Izah, S. C., Chakrabarty, N. and Srivastav, A. L. (2016). A Review on Heavy Metal Concentration in Potable Water Sources in Nigeria: Human Health Effects and Mitigating Measures. Exposure and Health, 8: 285-304.

[11] Izah, S. C. and Srivastav, A. L. (2015). Level of arsenic in potable water sources in Nigeria and their potential health impacts: A review. Journal of Environmental Treatment Techniques, 3 (1): 15-24.

[12] Izah, S. C. and Ineyougha, E. R. (2015). A review of the microbial quality of potable water sources in Nigeria. Journal of Advances in Biological and Basic Research, 1 (1): 12-19.

[13] Seiyaboh, E. I., Izah, S. C. and Oweibi, S. (2017). Assessment of Water quality from Sagbama Creek, Niger Delta, Nigeria. Biotechnological Research, 3 (1): 20-24.

[14] Seiyaboh, E. I. and Izah, S. C. (2017). A Review of Impacts of Gas Flaring on Vegetation and Water Resources in the Niger Delta Region of Nigeria. International Journal of Economy, Energy and Environment, 2 (4): 48-55.

[15] Seiyaboh, E. I. and Izah, S. C. (2017). Bacteriological assessment of a tidal creek receiving slaughterhouse wastes in Bayelsa state, Nigeria. Journal of Advances in Biology and Biotechnology, 14 (1): 1-7.

[16] Seiyaboh, E. I. and Izah, S. C. (2017). Review of Impact of Anthropogenic Activities in Surface Water Resources in the Niger Delta region of Nigeria: A case of Bayelsa state. International Journal of Ecotoxicology and Ecobiology. 2 (2): 61-73.

[17] Chindah, A. C. and Braide, S. A. (2003). Cadmium and Lead concentrations in fish species of a brackish wetland / upper Bonny Estuary, Niger Delta. J. Nig. Environ. Soc. (JNES) 1 (3): 399-405

[18] Agedah, E. C., Ineyougha, E. R., Izah, S. C. and Orutugu, L. A. (2015). Enumeration of total heterotrophic bacteria and some physico-chemical characteristics of surface water used for drinking sources in Wilberforce Island, Nigeria. Journal of Environmental Treatment Techniques, 3 (1): 28-34.
[19] Ogamba, E. N., Izah, S. C. and Oribu, T. (2015). Water quality and proximate analysis of Eichhornia crassipes from River Nun, Amassoma Axis, Nigeria. Research Journal of Phytomedicine, 1 (1): 43-48.

[20] Ogamba, E. N., Izah, S. C. and Toikumo, B. P. (2015). Water quality and levels of lead and mercury in Eichhornia crassipes from a tidal creek receiving abattoir effluent, in the Niger Delta, Nigeria. Continental Journal of Environmental Science, 9 (1): 13-25.

[21] Ogamba, E. N., Seiyaboh, E. I., Izah, S. C., Ogbugo, I. and Demedongha, F. K. (2015). Water quality, phytochemistry and proximate constituents of Eichhornia crassipes from Kolo creek, Niger Delta, Nigeria. International Journal of Applied Research and Technology, 4 (9): 77-84.

[22] Ben-Eledo, V. N., Kigigha, L. T., Izah, S. C. and Eledo, B. O. (2017). Bacteriological Quality Assessment of Epie Creek, Niger Delta Region of Nigeria. International Journal of Ecotoxicology and Ecobiology, (3): 102-108.

[23] Ben-Eledo, V. N., Kigigha, L. T., Izah, S. C. and Eledo, B. O. (2017). Water quality assessment of Epie creek in Yenagoa metropolis, Bayelsa state, Nigeria. Archives of Current Research International, 8 (2): 1-24.

[24] Fatoba, P. O., Ogunkunle, C. O. and Ihaza, C. O. (2015). Assessment of Metal Pollution of Soil and Diagnostic Species Associated with Oil Spills in the Niger Delta, Nigeria. Environmental Research, Engineering and Management, 71 (3): $13-22$.

[25] American Public Health Association (APHA). (1995). Standard Methods for the examination of water and wastewater, 19th ed. American Public Health Association, Inc. New York.

[26] Department of Petroleum Resources (DPR) (2002). Environmental Guidelines and Standards for the Petroleum Industry in Nigeria, DPR, Lagos, Nigeria, Pg 14, 109, 280.

[27] Federal Ministry of Environment (FME) (2001). National Guidelines and Standards for Water Quality in Nigeria. Pg 2526.

[28] National Environmental Standards and Regulation Enforcement Agency (NESREA) (2009). National Environmental (Sanitation and Wastes Control): Quality Standards for Sources of Domestic Water, Abuja, Nigeria, Pg B1086-1087.

[29] WHO, World Health Organization (1993). Guidelines for Drinking-Water Quality. World $\backslash$ Health Organization, Geneva 1993. 